\title{
Evaluation of farm yard manure (sheep bedding) on the soil fertility, leaf mineral composition, and growth performance of oil palm seedlings
}

\author{
E. Larbi ${ }^{\star}$, S. Anim-Okyere, F. Danso and I. Danso \\ CSIR- Oil Palm Research Institute, P.O. Box 74, Kade, Ghana. \\ ${ }^{*}$ Corresponding author. Email: eklarbi2005@gmail.com
}

\begin{abstract}
Copyright ( 2019 Larbi et al. This article remains permanently open access under the terms of the Creative Commons Attribution License 4.0, which
\end{abstract} permits unrestricted use, distribution, and reproduction in any medium, provided the original work is properly cited.

Received 27th February 2018; Accepted 9th April 2018

\begin{abstract}
This study was conducted to evaluate the growth performance and leaf mineral composition of oil palm seedlings as influenced by the application of sheep manure. Partially decomposed farmyard manure from sheep was mixed with soil and filled into polybags $(28 \mathrm{~cm} \times 35 \mathrm{~cm}$ lay flat) in proportions as treatments: $(25 \%$ soil: $75 \%$ FYM); $(50 \%$ soil: $50 \%$ FYM); (75\% soil: $25 \%$ FYM); and (100\% soil + NPK 15:15:15) as control. The treatments were laid out in Randomized Complete Block Design (RCBD) with four (4) replications. Assessment was made for morphological growth (plant height, leaf number, and butt circumference), physiological growth (crown and root biomass) and leaf nutrients status analysed for $\mathrm{N}, \mathrm{P}, \mathrm{K}, \mathrm{Ca}$ and $\mathrm{Mg}$. There was no significant $(\mathrm{p} \leq 0.05)$ difference observed in growth parameters. It was however observed that treatments with a higher amount of manure ( $25 \%$ soil: $75 \%$ FYM) showed significantly ( $p \leq$ 0.05 ) higher biomass production than the control. The leaf nutrients analysis for $\mathrm{N}, \mathrm{P}, \mathrm{K}, \mathrm{Ca}$ and $\mathrm{Mg}$ indicated lower concentration than their respective optimum levels. This study revealed that oil palm seedlings can grow well on soil amended with farmyard manure from sheep and that higher percentage of $25 \%$ soil: $75 \%$ FYM seem more promising. The FYM application will help boost the vegetative growth of oil palm seedling thus reducing inorganic fertilizer application in the nursery.
\end{abstract}

Keywords: Farmyard manure, leaf nutrient status, nursery, seedling, sheep bedding.

\section{INTRODUCTION}

The oil palm (Elaeis guineensis Jacq) tree is a highly demanding crop for nutrients both for early growth and production, hence requiring high inherent soil fertility status. Oil palm requires more agronomic inputs when planted on soils with low inherent fertility, to ensure adequate growth and yields (Sabrina et al., 2009). Fertilizers are therefore applied to oil palm seedlings at the nurseries principally to produce seedlings with the needed vigour to perform well in the field. This is necessary because it is either difficult or impossible to compensate for incorrect practices applied from seed quality through to early field management which will result in considerable loss of oil per hectare (Griffee et al., 2004). However, with the increasing cost of inorganic fertilizers in recent years, and growing concern on health hazards posed by chemical fertilizers, on the environment, there is now a concerted effort to review the use of these fertilizers and to place more emphasis on the use of organic fertilizers. The high cost of inorganic fertilizers and its scarcity makes it even more difficult for the resource-poor farmer to afford. In the face of declining soil fertility, there is the need to look for alternative sources of organic fertilizer materials which are cheap, sustainable and environmentally compatible to raise oil palm seedlings in large quantities for the establishment of plantations. The use of manure obtained from oil palm - sheep integration becomes a readily available source of organic manure and alternative source of plant nutrient. This is also an important means to maintain organic matter and humus levels in the soil (Adams et al., 1997). 
The organic matter levels influence physical and chemical properties of the soil as well as accounting for as much as one-third of Cation Exchange Capacity (CEC) of the soil surface and it is also responsible for the stability of soil aggregates (Brady, 1990). Tisdale et al., (1990) reported the benefits of manure to include an additional supply of ammonium nitrate $\left(\mathrm{NH}_{4} \mathrm{NO}_{3}\right)$, increased moisture retention, improved soil structure with corresponding increase in infiltration rate and a decrease in bulk density. Additionally, it increases buffering capacity against drastic changes in $\mathrm{pH}$ and complexation of Aluminium ions $\left(\mathrm{Al}^{3+}\right)$ thereby reducing its toxicity. The use of such by-product as manure means converting waste from one component of the production system into a useful economic product. Research has shown that the use of manure with high bacterial content provides both ammonia and slow breakdown of bacterial cell wall stimulating actinomycetes (White, 1999). This ammonia serves as a source of nitrogen which is essential for plant growth. There are several reports on the use of organic matter in raising seedling of tree crops such mango and cola (Moyin- Jesu and Adeofun 2008) and grow several vegetables (Munzzaman et al., 2003). However, no such information can be found on oil palm seedlings. Therefore, there is need to think of manure as an economically valuable byproduct of oil palm-sheep integration and give more attention to the collection and utilization of such product, based on sound research results hence this study. Thus, the objectives of this study were to:

1. evaluate the growth performance of oil palm seedlings as influenced by the application of farmyard manure in the nursery.

2. determine the effect of this organic fertilizer on the leaf mineral composition of oil palm seedlings.

3. determine the effect of farmyard manure on soil nutrient dynamics.

\section{MATERIAL AND METHODS}

The study was carried out at CSIR- Oil Palm Research Institute, Kusi, Ghana. The climatic condition of the area is $1600 \mathrm{~mm}$ of rainfall per annum, a temperature range of 22 to $33^{\circ} \mathrm{C}$ and average sunshine of 6 hours per day.

\section{Experimental design}

There were five treatments, consisting of different proportions of topsoil and Farmyard Manure (FYM) to form the growth medium. Polybag $(28 \mathrm{~cm} \times 35 \mathrm{~cm})$ were filled with the Soil: FYM proportions stated below:

T1 $=25 \%$ soil: $75 \%$ FYM

T2 $=50 \%$ soil: $50 \%$ FYM

T3 $=75 \%$ soil: $25 \%$ FYM

T4 = Soil + NPK 15:15:15 (control)
The polybags were arranged at the nursery and spaced at $0.75 \mathrm{~m}$ triangular. Each plot contained 20 oil palms seedlings, giving a population of 80 seedlings per treatment. Six palms in the inner rows were tagged for sampling. The experiment was laid out in Randomized Complete Block Design (RCBD) of four blocks with five treatments in each block. The control contained topsoil fertilized with NPK 15:15:15 compound fertilizer. From the 6th month until the 12th month after transplanting, $25 \mathrm{~g}$ of NPK was applied to each seedling of the control on monthly bases.

\section{Source of Farmyard Manure}

The farmyard manure was obtained from the livestock section of CSIR-OPRI. It is composed of wood shavings impregnated with faeces and urine from sheep. The farmyard manure was heaped under shade for one year and was mixed with soil in the proportions stated above by volume to form the treatments. The growth mediums formulated were filled into polybags $(28 \times 35 \mathrm{~cm})$ and were left for four months to settle. Prior to seedling transplanting, the polybags were topped-up with the respective formulations leaving a space of $2.5 \mathrm{~cm}$ at the top for watering.

\section{Cultural practices}

Watering started immediately after transplanting and continued every morning until the seedlings were fully established. Thereafter, watering continued every other day. Weeds in the bags were hand-picked manually, while those in the inter-rows were controlled with herbicide. Pruning was carried out to remove dry leaves, while pests and diseases were also controlled when it became necessary.

\section{Soil sampling and analysis}

The growth media were analyzed to assess their physicochemical composition before and after the trial. This covered Soil Texture, Available Water Capacity, Organic Carbon, pH, Total Phosphorus, Total Nitrogen, available Phosphorus, Cation Exchange Capacity.

The growth media were air dried, pulverized and sieved with $2 \mathrm{~mm}$ mesh sieve. Particle size distribution was carried out through hydrometer method (Gee and Bauder, 1986). Organic carbon was also determined by dichromate oxidation Nelson et al. (1982) method. Soil pH was determined in a 1:2.5 (soil:water) solution using $\mathrm{pH}$ meter (Mclean, 1982). Exchangeable bases, available phosphorus (avail P) were extracted with Bray No.1 (Bray 1945). The nitrogen content was determined by Kjeldahl digestion method while the determination of other nutrients 
such as $\mathrm{P}, \mathrm{K}, \mathrm{Ca}$ and $\mathrm{Mg}$, were done using the wet digestion method based on 25-5-5 ml of $\mathrm{HNO}_{3}-\mathrm{H}_{2} \mathrm{SO}_{4}-$ $\mathrm{HClO}_{4}$ acids (AOAC, 1970).

\section{Data collection}

Growth response was evaluated as plant height, butt circumference, number of leaves, leaf area, leaf area index and frond dry weight.

\section{Plant height}

Plant height was measured from the soil surface in the polybag to the highest point of the spear leaf.

\section{Leaf area}

Leaf area (LA) was estimated using the Hardon et al. (1969) equation:

LA $\left(m^{2}\right)=b(n \times L W)$

Where: $b=$ correction factor; (using a correction factor of $0.55), n=$ number of leaflets per leaf; $L=$ mean length and $\mathrm{W}=$ mid-width of largest leaflets

\section{Leaf area index (LAI)}

Leaf Area Index (LAl) was estimated by expressing the values obtained for leaf area as a ratio to the ground area. LAI was thus estimated as:

LAI $=\frac{\text { Leaf area }}{\text { Ground area }}$

\section{Frond dry weight (FDW)}

A pair of callipers was used to measure the radius and depth of petiole, at the point of insertion of the lowest leaflet. The values obtained were put into the formula to estimate the frond dry weight using the method described by Corley (1971).

FDW $=0.1026$ width $x$ depth $+0.2362(\mathrm{~kg})$

Growth response evaluation started in the sixth month after transplanting (MAT) and continued monthly until the 12th month.

Representative leaf samples from the middle of a fully opened frond of the seedlings were randomly taken at 12 months after transplanting per each treatment using a knife, packed into labeled envelopes and oven dried for 24 hours at $70^{\circ} \mathrm{C}$. The dried leaf samples were ashed using a muffle furnace at $450^{\circ} \mathrm{C}$ for six hours. The ash was made into a $50 \mathrm{ml}$ solution, filtered and analysed for $\mathrm{N}, \mathrm{P}, \mathrm{K}, \mathrm{Ca}$ and $\mathrm{Mg}$ contents as described by AOAC (1970).

\section{Data analyses}

The data collected was subjected to statistical analysis. Analysis of variance (ANOVA), for the data was carried out using (Genstat statistical package, version 16.0). Significant differences between means were estimated by the Least Significant Difference at $5 \%$ level of significance".

\section{RESULTS}

The physicochemical properties of the growth media prior to planting of oil palm seedlings are presented in Table 1. The analysis of the growth media showed that the $\mathrm{pH}$ of the growth medium for $T_{1}-T_{3}$ was alkaline, while $T_{4}$ was slightly acidic suitable for growth of oil palm. The organic matter ranged from 1.14 to $4.5 \%$. T1 had the highest value of $4.5 \%$ whilst the lowest value of $1.14 \%$ was recorded for $\mathrm{T}_{4}$. Generally, the higher the farmyard manure the higher the organic matter levels. The application of farmyard manure increased the soil $\mathrm{N}, \mathrm{P}, \mathrm{K}, \mathrm{Ca}, \mathrm{Mg}, \mathrm{pH}$ and organic matter significantly $(P \leq 0.05)$ relative to the control treatment (Table 1). Mechanically the soils were not homogeneous as $T_{1}-T_{3}$ contained more sand than $T_{4}$.

\section{Seedling height}

Variations in seedling height observed due to the application of farmyard manure in soil $(P<0.05)$ over a period of 12 months is shown in Table 2. Seedling height increased gradually from 6 MAT to 11 MAT, irrespective of the treatments. At 7 MAT there was significant $(P \leq 0.05)$ variation in height between $\mathrm{T}_{3}$ and $\mathrm{T}_{4}$. At 11th month after transplanting $T_{4}$ had the highest seedling height (118.20 $\mathrm{cm})$ while the lowest was recorded in $T_{2}(80.50 \mathrm{~cm})$. From $6 \mathrm{MAT}$ to $7 \mathrm{MAT}, \mathrm{T}_{4}$ recorded the lowest value for seedling height. An indication that the fertilizer applied may not have produced any effect yet. Consequently, with the passage of time, there was a change in the growth rate of $\mathrm{T}_{4}$. This difference, however, disappeared with time. This may be attributed to low levels of $\mathrm{N}$ contained in the $\mathrm{T}_{4}$ prior to the application of inorganic fertilizer.

\section{Number of leaves}

The effect of treatment on mean number of fronds of oil palm seedling is presented in Table 3 . For all the treatments, leaf production was gradual throughout the period of observation. The least number and the highest number of fronds were recorded in $\mathrm{T}_{4}(4.88)$ at 6 MAT and 
Table 1. Physico-chemical properties of the growth media before planting oil palm Seedlings.

\begin{tabular}{lcccc}
\hline \multirow{2}{*}{ Chemical properties of growth medium } & \multicolumn{4}{c}{ Treatments } \\
\cline { 2 - 5 } & T1 & T2 & T3 & T4 \\
\hline pH (1:1) & 8.80 & 8.40 & 8.50 & 6.10 \\
Organic matter (\%) & 4.50 & 2.55 & 2.90 & 1.14 \\
Organic carbon (\%) & 2.61 & 1.48 & 1.68 & 1.25 \\
Total Nitrogen (\%) & 0.27 & 0.16 & 0.17 & 0.10 \\
Available Bray 1 (mgP/kg) & & & & \\
P & & & & \\
K & 310.14 & 122.78 & 78.13 & 38.43 \\
& 465.46 & 811.86 & 719.85 & 113.66 \\
Exchangeable bases (cmol/kg) & & & & \\
Mg & & & & \\
K & 4.81 & 2.27 & 2.67 & 1.87 \\
Ca & 5.25 & 3.08 & 3.68 & 2.80 \\
Na & 15.49 & 4.81 & 8.01 & 2.40 \\
Total Exchangeable Base & 2.40 & 1.20 & 1.50 & 0.90 \\
Exchangeable Acidity (cmol/kg) & 27.95 & 11.36 & 15.86 & 7.10 \\
ECEC (cmol/kg) & 0.02 & 0.03 & 0.02 & 0.15 \\
Base saturation (\%) & 27.97 & 11.39 & 15.88 & 7.25 \\
\% Sand & 99.93 & 99.74 & 99.87 & 97.93 \\
\% Clay & 83.32 & 83.32 & 72.32 & 49.32 \\
\% Silt & 6.68 & 6.68 & 10.68 & 14.68 \\
\hline
\end{tabular}

Table 2. Effect of treatments on mean height of oil palm seedling (cm).

\begin{tabular}{lccccccc}
\hline & \multicolumn{7}{c}{ Months after transplanting } \\
\cline { 2 - 8 } Treatments & $\mathbf{6}$ & $\mathbf{7}$ & $\mathbf{8}$ & $\mathbf{9}$ & $\mathbf{1 0}$ & $\mathbf{1 1}$ & $\mathbf{1 2}$ \\
\hline T1 & 56.79 & 55.46 & 64.50 & 69.25 & 99.75 & 103.62 & 100.62 \\
T2 & 58.13 & 61.54 & 64.50 & 67.25 & 97.50 & $80.50^{*}$ & 89.00 \\
T3 & 59.29 & 62.25 & 62.25 & 66.25 & 92.75 & 101.25 & 97.12 \\
T4 & 49.37 & 51.75 & 68.40 & 72.30 & 108.30 & $118.20^{*}$ & 94.38 \\
LSD $(0.05)$ & 10.43 & 10.35 & 10.44 & 12.18 & 24.39 & $35.51 \mathrm{~s}$ & 25.53 \\
\hline
\end{tabular}

Table 3. Effect of treatments on mean number of fronds of oil palm seedling.

\begin{tabular}{lccccccc}
\hline \multirow{2}{*}{ Treatments } & \multicolumn{7}{c}{ Months after transplanting (MAT) } \\
\cline { 2 - 8 } & $\mathbf{6}$ & $\mathbf{7}$ & $\mathbf{8}$ & $\mathbf{9}$ & $\mathbf{1 0}$ & $\mathbf{1 1}$ & $\mathbf{1 2}$ \\
\hline T1 & 5.54 & 5.92 & 7.77 & 7.25 & 7.75 & 8.75 & 10.00 \\
T2 & 6.29 & 6.62 & 7.71 & 7.92 & 7.50 & 8.50 & 9.25 \\
T3 & 5.58 & 5.33 & 7.04 & 7.55 & 7.50 & 8.50 & 8.75 \\
T4 & 4.88 & 4.71 & 5.88 & 7.42 & 7.75 & 8.75 & 10.01 \\
LSD (0.05) & 0.88 & 0.97 & 0.845 & 1.40 & 1.27 & 1.39 & 2.10 \\
\hline
\end{tabular}

(10.01) at 12 MAT respectively. From 6 MAT to 8 MAT, $T_{2}$ recorded significantly higher number of fronds than $\mathrm{T}_{4}$ (the control).

\section{Butt circumference}

Table 4 shows the increase in butt expansion of oil palm 
Table 4. Effect of treatments on the mean butt circumference of oil palm seedling $(\mathrm{cm})$.

\begin{tabular}{lcccccc}
\hline \multirow{2}{*}{ Treatments } & \multicolumn{7}{c}{ Months after transplanting } \\
\cline { 2 - 7 } & $\mathbf{6}$ & $\mathbf{7}$ & $\mathbf{8}$ & $\mathbf{9}$ & $\mathbf{1 0}$ & $\mathbf{1 1}$ \\
\hline T1 & 9.07 & 10.90 & 12.51 & 12.47 & 15.75 & 16.11 \\
T2 & 9.13 & 10.66 & 12.60 & 13.49 & 15.14 & 15.47 \\
T3 & 8.94 & 10.64 & 12.25 & 13.54 & 14.59 & 14.68 \\
T4 & 7.69 & 8.91 & 12.35 & 13.62 & 16.13 & 16.19 \\
LSD $(0.05)$ & 1.76 & $1.53 s$ & 1.66 & 2.04 & 1.36 & 2.58 \\
\hline
\end{tabular}

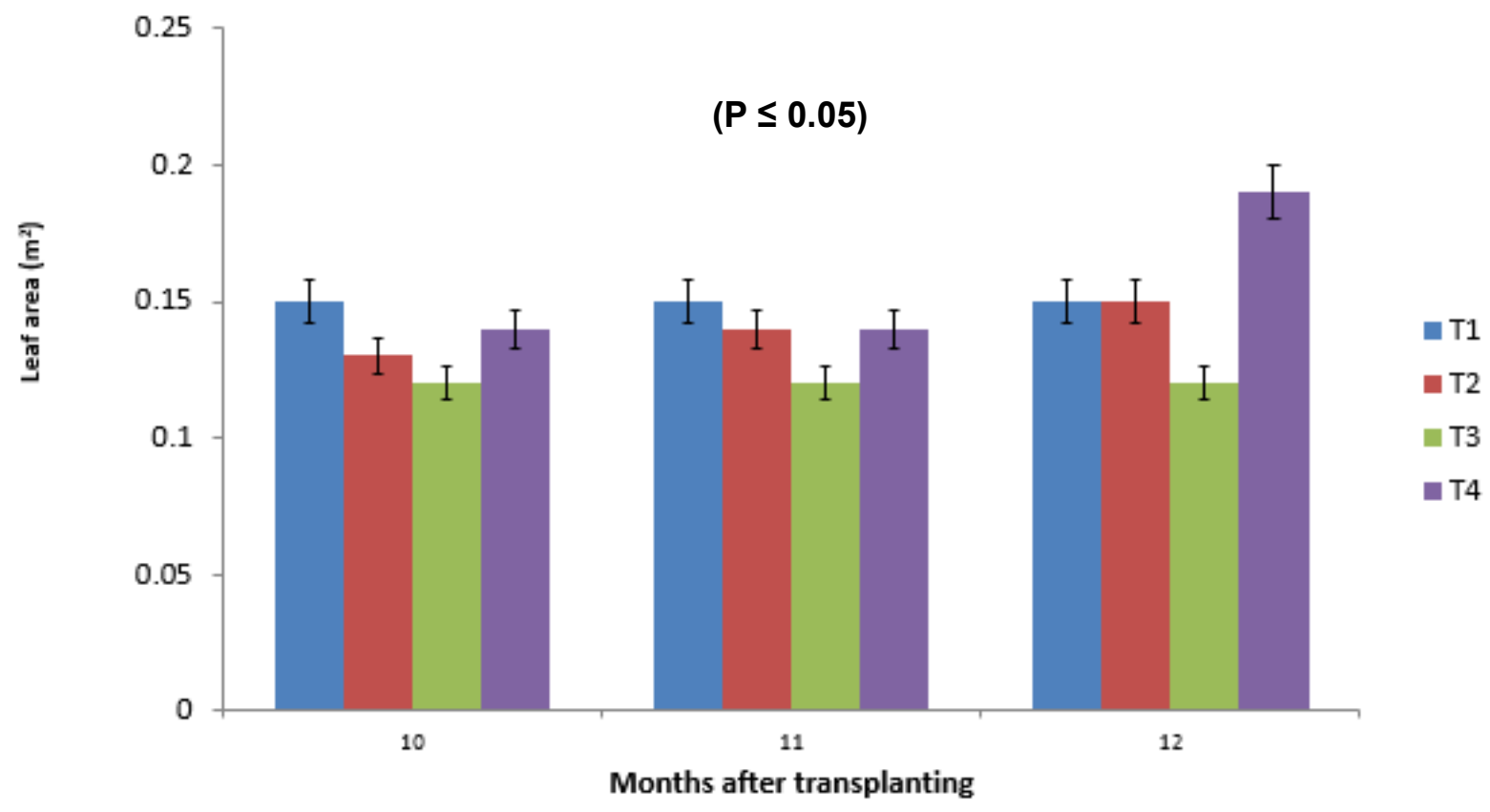

Figure 1. Effect of farm yard manure on leaf area of oil palm seedling.

seedling as influenced by the application of farmyard manure. Butt expansion was gradual during the experimental period. However, lower values were recorded in $T_{4}$ at 6 MAT and 7 MAT respectively. These values were also significantly lower than the rest of the treatments.

\section{Leaf area (LA)}

Figure 1 shows the effect of treatments on leaf area of oil palm seedling. Leaf area values for $\mathrm{T}_{3}$ were significantly lower than all the other treatments from 10 MAT to 12 MAT. At 12MAT, $\mathrm{T}_{4}$ had larger leaf area than all treatments. The value $\left(0.17 \mathrm{~m}^{2}\right)$ was significantly higher than other treatments.

\section{Leaf area index (LAI)}

Treatment effects on the leaf area index are presented in
Figure 2. During the period of the experiment, the lowest LAI value (1.18) was recorded in $T_{3}$ at 10 MAT. This value was significantly $(P \leq 0.05)$ lower than $T_{4}$. This trend continued throughout the trial period. There was however no significant difference observed between the control $\left(\mathrm{T}_{4}\right)$ and other treatments.

\section{Frond dry weight}

Effects of treatments on frond dry weight (FDW) are presented in Figure 3. $T_{4}$ recorded the highest FDW from 10 MAT to 12 MAT ranging from 0.35 to $0.38 \mathrm{~kg}$. These values were significantly $(P \leq 0.05)$ higher than all other treatments.

Data on dry matter accumulation since planting to 12 MAP are presented in Table 5. Dry matter partitioning after destructive analysis at the end of the trial indicates that the leaf together with petiole constitutes a fraction greater than $50 \%$ of total dry matter accumulated across all the 


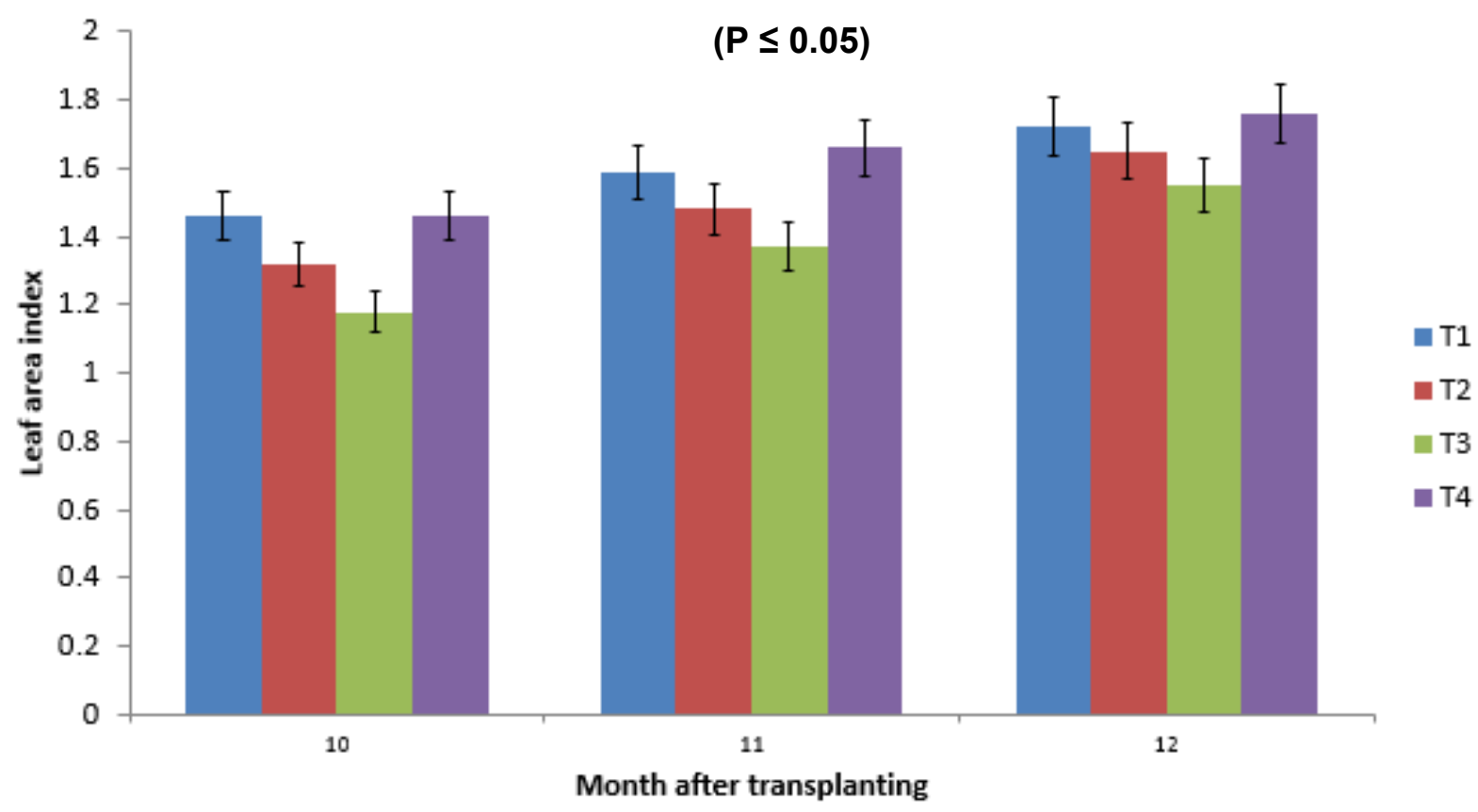

Figure 2. Effect of farm yard manure on leaf area index of oil palm seedling.

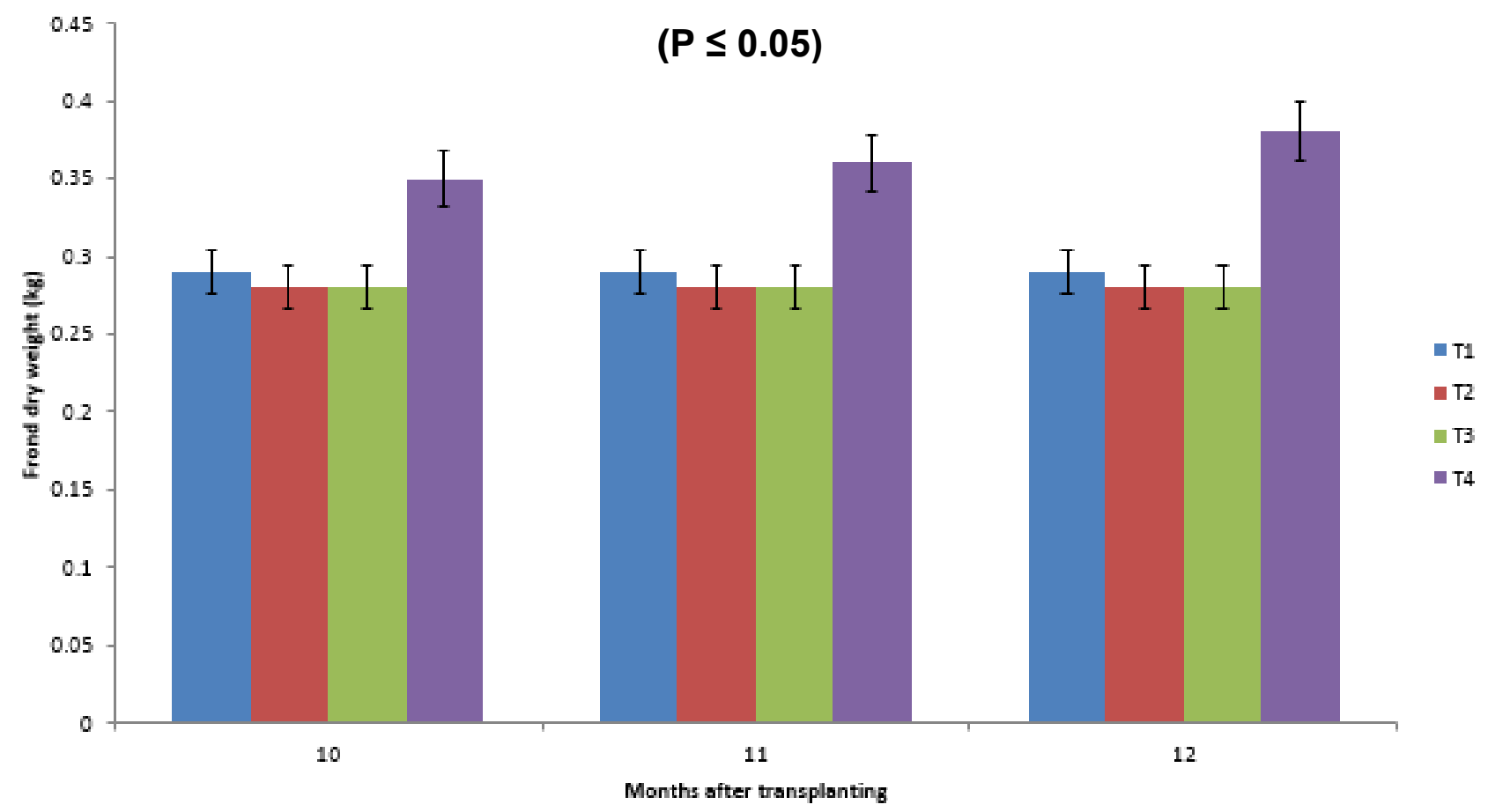

Figure 3. Effect of farm yard manure on frond dry weight of oil palm seedling.

treatments (Table 5). Conversely, below ground allocation was higher in all the FYM treatments than the control. Dry matter accumulation and partitioning were not significantly $(P \leq 0.05)$ affected by the treatments. It is evident that more biomass was allocated to above ground tissues in all treatments. Root biomass in $\mathrm{T}_{4}$ was however significantly $(p \leq 0.05)$ lower than the rest except $T_{3}$. Even though treatments did not significantly affect dry matter accumulation in its totality, it was observed that dry matter accumulation and partitioning were directly proportional to 
Table 5. Effect of farmyard manure on dry matter accumulation and partitioning.

\begin{tabular}{lcccc}
\hline \multirow{2}{*}{ Treatments } & \multicolumn{4}{c}{ Dry matter Accumulation(g) } \\
\cline { 2 - 5 } & Leaves & Butt & Root & Total \\
\hline T1 & 293.9 & 153.1 & 66.0 & 513 \\
T2 & 251.3 & 119.2 & 64.1 & 435 \\
T3 & 227.3 & 96.1 & 50.3 & 374 \\
T4 & 206.6 & 90.0 & 39.4 & 336 \\
LSD $(0.05)$ & 148.83 & 35.69 & 18.32 & 185 \\
CV \% & 29.0 & 18.5 & 11.9 & 22.9 \\
\hline
\end{tabular}

Table 6. Effect of farmyard manure on leaf nutrients status of seedlings at 12MAT.

\begin{tabular}{lllllc}
\hline Treatments & $\mathbf{N}(\%)$ & $\mathbf{P}(\%)$ & $\mathbf{K}(\%)$ & $\mathbf{C a}(\%)$ & $\mathbf{M g}(\%)$ \\
\hline $\mathrm{T}_{1}$ & 2.73 & 0.29 & 1.11 & 0.66 & 0.21 \\
$\mathrm{~T}_{2}$ & 2.49 & 0.31 & 1.09 & 0.63 & 0.32 \\
$\mathrm{~T}_{3}$ & 2.43 & 0.13 & 1.11 & 0.68 & 0.16 \\
$\mathrm{~T}_{4}$ & 3.14 & 0.20 & 1.02 & 0.82 & 0.23 \\
\hline
\end{tabular}

the amount of manure applied.

\section{Leaf nutrient concentrations}

Leaf nutrient profiles of the treatments of palms after 12 MAT are presented in Table 6 . Leaf $\mathrm{N}$ content was slightly higher across all treatments relative to the critical value of $2.50 \%$. Similarly, leaf $\mathrm{K}, \mathrm{Ca}$ and $\mathrm{Mg}$ contents were observed to be slightly higher than their respective reference critical values of $1 \%, 0.6 \%$, and $0.24 \%$. Leaf $P$ content was found to be within optimum levels in all thetreatments except $T_{3}$ which recorded a value lower than the critical value of $0.15 \%$.

\section{DISCUSSION}

An adequate supply of soil nutrients is one of the essential factors determining growth performance and yield of oil palm. A good fertilizer management programme is important to achieve good soil nutrient status that will sustain oil palm seedling growth and development and consequently produce higher yields. The seedlings therefore must receive adequate nutrients in balanced proportion to ensure healthy vegetative growth, development and subsequently good yields. The statistical analysis of growth response of the oil palm seedlings to treatment application did not vary much across the sampling period. The early expansion of the canopy in the young palms facilitates radiation capture, which is of crucial importance for yield (Henson, 1991). The nonsignificant result observed in leaf area index and in number of leaves could be attributed to the fact that organic fertilizer may have retained water and consequently nutrients in the soil solution for plant uptake. This effect may be due to the availability of nutrients and the improvement of soil water holding capacity as stated by Roe and Comforth (2000). A similar observation has also been reported by Cheng-xu et al. (2011).

The leaf area of the crown and the shape of crowns determine light interception and this influences the yield of palms (Breure 1985). In this study, treatment with least organic matter $\left(T_{3}\right)$ showed significantly lower leaf area and leaf area index. This may be attributed to the low amount of $\mathrm{N}$ levels recorded since $\mathrm{N}$ is responsible for the increase in leaf area up to $30 \%$ (Corley and Tinker, 2003).

It was observed that growth of the butt was gradual across the experimental period. The highest butt circumference of oil palm seedling was obtained by the application of inorganic fertilizer $\left(T_{4}\right)$, however, this was not significantly different from other treatments. This is however contrary to the positive effect of the inorganic fertilizer on the girth of oil palm seedlings as reported by Arisha et al. (2003), while the positive effect of farmyard manure on the butt circumference may be due to the improvement of soil chemical and physical properties in the same report.

\section{Dry matter accumulation and partitioning}

Solar radiation is important for both growth and bunch production (Verheye, 2010). Generally, photosynthetically active radiation (PAR) intercepted by the crop canopy is considered to be directly proportional to the dry matter accumulated (Monteith and Moss, 1977). Dry matter yields increased with increasing manure application rate. Treatments with higher amount of manure showed higher biomass production than the control. This is in agreement 
with Mhlontlo et al. (2007) who reported a similar trend in Amaranthus treated with sheep kraal manure. However, the farmyard manure promoted better root growth. Evidence of which is supported by Suryanto et al. (2015). This may account for non-significant growth observed morphologically since the farmyard manure provided a better medium for root growth, promoting a better root function of nutrient and water uptake. Application of organic manure has been observed to improve water infiltration and retention (Bationo et al., 1998; Agassi et al., 2004) and the available water content of soils by 58 to $86 \%$ (Celik et al., 2004), making available water in the root zone for better growth.

Goh and Hardter (2003) again reported that the mineral nutrient content of oil palm frond is influenced by the nutrient status of the soil. Foster (2003) stated, "leaf analysis is perhaps the most common diagnostic tool to determine the nutritional status of oil palm". The results from this study indicated a slightly higher leaf nutrient concentrations when compared with their respective critical value as stated in (IRHO, 1960) required to promote better growth in oil palm. The addition of manure influences nutrient availability and retention of nutrient in the growth medium and in addition promotes uptake (Adler et al., 2009).

\section{Conclusion}

The farmyard manure was observed to be a vegetative enhancer. One of the most expensive components of the oil palm industry is fertilizer. This study revealed that oil palm seedlings can grow well on soil amended with farmyard manure from sheep and that higher percentage of $25 \%$ soil: $75 \%$ FYM seem more promising. The FYM application will help boost the vegetative growth of oil palm seedling thus reducing inorganic fertilizer application in the nursery.

\section{ACKNOWLEDGEMENT}

The authors express profound gratitude to all the technical staff of the Agronomy Division of the Council for Scientific and Industrial Research - Oil Palm Research Institute, (CSIR-OPRI), Kusi for their technical assistance. We also express our sincere gratitude to the Director, CSIR-OPRI under whose permission this paper is published.

\section{REFERENCES}

Adams, C. R., Bamford, K. M., \& Early, M. P. (1997). Principles of Horticulture, Bath Press, Avon, Great Britain.

Adler, P. R., Jonathan, R., \& Cumming, R. A. (2009). Nature of Mineral Nutrient Uptake by Plants In: Rattan Lal (ed), Agricultural Sciences - Vol. I. EOLSS Publications.

AOAC (1970). Official methods of Analysis 12th ed., Association of Official Analytical Chemists, Arlington, VA.
Agassi, M., Levy, G. J., Hadas, A., Benyamini, Y., Zhevelev, H., Fizik, E., Gotessman, M., \& Sasson, N. (2004). Mulching with composted municipal solid wastes in Central Negev. Israel: I. Effects on minimizing rainwater losses and on hazards to the environment. Soil and Tillage Research, 78(1), 103-113.

Arisha, H. M. E., Gad, A. A., \& Younes, S. E. (2003). Response of some pepper cultivars to organic and mineral nitrogen fertilizer under sandy soil conditions. Zagazig J. Agric. Res., 30, 1875-99.

Bationo, A., Lompo, F., \& Koala, S. (1998). Research on nutrient flows and balances in West Africa: state-of-the-art. Agriculture, Ecosystems and Environment, 71(1-3), 19-35.

Brady, N. C. (1990). The Nature and Property of Soils, Macmillan Publishers Ltd., London.

Breure, C. J., \& Foster, H. L. (2002). Responses of yield, growth and leaf nutrient levels to $\mathrm{N}, \mathrm{P}, \mathrm{K}$ and $\mathrm{Mg}$ fertilizers on two different soil series in South Sumatra. In: 2002 International Oil Palm Conference and Exhibition. Bali, Indonesia.8-12 July 2002. IOPRI. Pp. 1-14.

Celik, I., Ortas, I., \& Kilic S, (2004). Effects of compost, mycorrhiza, manure and fertilizer on some physical properties of a Chromoxerert soil. Soil Tillage Research, 78(1), 59-67.

Cheng-xu, S., Hong-xing, C., Hong-bo, S., Xin-tao, L., \& Yong, X. (2011). Growth and Physiological responses to water and nutrient stress in oil palm. African Journal of Biotechnology, 10(51), 10465-10471.

Corley, R. H. V. Tinker, P. B. (2003). 'The oil Palm.' 4th edn. (Blackwell Science: Oxford).

Corley, R. H. V. (1971). Analysis of growth and the oil palm (Elaeis guineensis Jacq) I. Estimation of growth parameters and application. Bree ex. T. Euphtica. Corley, RHV.

Foster, H. L. (2003). Assessment of Oil Palm Fertiliser Requirements. In. Fairhurst T, Härdter R), (ed) 'Oil palm: Management for larger and sustainable yields' Potash \& Phosphate Institute/Potash \& Phosphate Institute of Canada and International Potash Institute, Singapore.

Gee, G. W., \& Bauder, J. W. (1986). "Particle Size Analysis," In: A. Klute, Ed., Methods Soil Analysis: Part 1, Agronomy Society of America and Soil Science Society of America, Madison. Pp. 404-407.

Goh, K. J., \& Härdter, R. (2003). General oil palm nutrition. In: Fairhurst, T H and Härdter, R (eds.) Oil Palm -Management for large and sustainable yields. International Plant Nutrition Institute (IPNI) and International Potash Institute (IPI).

Griffee, P., Diemer, P., \& Chinchilla, C. (2004). Smallholder Oil Palm Manual. FAO and ASD- Costa Rica

Hardon, J. J., \& Williams, C. N. and Watson, I. (1969). Leaf Area and Yield in the Oil Palm in Malaya. Experimental Agriculture, 5, 25-32.

Henson, I. E. (1991). Limitations to gas exchange, growth and yield of young oil palm by soil water supply and atmospheric humidity. Transactions of Malaysian Society of Plant Physiology, 2, 39-45.

IRHO (1960). Institute de Researches pour les Huiles et Olleagineux, Rapporte Annueles 1960

McLean, E. O. (1982). Soil pH and Lime Requirement, In: A. I. Page, Ed., Methods of Soil Analysis, Part II, Agronomy Society of America and Soil Science Society of America, Madison, Pp. 199-223.

Bray, R. H., \& Kurtz, L. T. (1945). Determination of total, organic, and available forms of phosphorus in soils. Soil Science, 59: 39-45.

Mhlontlo, S., Muchaonyerwa, P., \& Mnkeni, P. N. S. (2007). Effects of sheep kraal manure on growth, dry matter yield and 
leaf nutrient composition of a local amaranthus accession in the central region of the Eastern Cape Province, South Africa. Water Sa, 33(3), 363-368.

Moyin-Jesu, E. I., \& Adeofun, C. O (2008). Comparative evaluation of different organic fertilizer on the soil fertility, leaf mineral composition, and growth performance of mango seedlings (Magnifera indica L.) Emir. J. Food Agric., 20(1), 1830

Monteith, J. L., \& Moss, C. J. (1977). Climate and the efficiency of crop production in Britain. Philosophical Transactions of the Royal Society of London. B, Biological Sciences, 281(980), 277-294.

Munzzaman, M. M., Ashrafuzzaman. M. Z., \& Islam, M. R. (2003). Field efficiency of biofertilizers on the growth of okra (Abelmoschus esculentus [(L.) Moench]. Journal of Plant Nutrition and Soil Science, 166(6), 764-770.

Nelson, D. W., \& Sommer, I. E. (1982). Total Carbon, Organic Carbon and Organic Matter," In: A. I. Page, Ed., Methods of Soil Analysis, Part II, Agronomy Society of America and Soil Science Society of America, Madison, Pp. 961-1010.

Roe, E. N., \& Comforth, C. G. (2000). Effect of dairy lot scraping and composted dairy manure on growth, yield and profit potential of double-cropped vegetables. Compost Sci. and Utilization, 8, 320-327.
Sabrina, D. T., Hanafi, M. M., Nor Azwady, A. A., \& Mahmud, T. M. M. (2009). Earthworm populations and cast properties in the soils of oil palm plantations. Malaysian Journal of Soil Science, 13, 29-42.

Suryanto, T., Wachyar, A., \& Supijatno (2015). The Growth of Oil Palm (Elaeis guineensis Jacq.) Seedlings at Various Media and Containers in Double Stage Nursery. Asian Journal of Applied Sciences, 3(5).

Tisdale, L. S., Nelson, W. L., \& Beaton. J. W. (1990). Soil fertility and soil Fertilizers. Macmillan Publishing Company. New York. Verheye, W. (2010). Growth and Production of Oil Palm. In: Verheye, W. (ed.), Land Use, Land Cover and Soil Sciences. Encyclopedia of Life Support Systems (EOLSS), UNESCOEOLSS Publishers, Oxford, UK. http://www.eolss.net

White, J. M. (1999). Organic Vegetable Production. UF Cooperative Extension Service. HS 720. (5). 